\title{
NOTES.
}

The Editor desires to point out that the pages of the Journal are open for the inclusion of short notes dealing with analytical practice and kindred matters. Such notes are submitted to the Publication Committee in the usual manner.

\section{GERMAN BREAD.}

Two samples of German bread which I have examined may be of interest. The first sample, No. 1, was sent from Germany to a German prisoner of war in this country during last September, and sample No. 2 was bread as supplied during the early part of the same month to British officer prisoners at Graudenz camp.

\begin{tabular}{|c|c|c|c|c|c|c|}
\hline Moisture & & & $10 \cdot 00^{\mathrm{N}}$ & cent. & $10 \cdot 00^{\mathrm{N}}$ & $\begin{array}{l}2 . \\
r \text { cent. }\end{array}$ \\
\hline Ash ... & $\cdots$ & … & $2 \cdot 30$ & " & $2 \cdot 60$ & $\mu$ \\
\hline Fat ... & $\ldots$ & $\ldots$ & 0.64 & " & 1.05 & $"$ \\
\hline Crude fibre & $\ldots$ & $\ldots$ & $2 \cdot 23$ & ", & $3 \cdot 12$ & , \\
\hline Proteins & $\ldots$ & $\ldots$ & $.9 \cdot 25$ & $"$ & $7 \cdot 68$ & $"$ \\
\hline Carbohydrates & $\ldots$ & $\ldots$ & $75 \cdot 58$ & ", & $75 \cdot 55$ & , \\
\hline
\end{tabular}

The fibre consisted of bran tissue, and in neither bread was sawdust detected, though sample No. 2 had evidently been dusted with sawdust, a little of which had stuck to a portion of the exterior of the loaf. There is no doubt that this sawdust had been used to prevent the loaf from sticking to the oven or vessel in which it had been baked.

Both breads were very dark coloured, and, as may be imagined from the moisture figures, were very dry. Probably they had been prepared from rye with the addition of potato.

SRssions House,

F. W. F. Arnavd.

MAIDSTONE.

\section{NOTE ON THE RELATION BETWEEN THE KIRSCHNER REICHERT- MEISSL AND POLENSKE FIGURES IN BUTTER.}

Bolton and Revis have worked out a relation between the Kirschner (K) and Polenske (P) values (ANALYsT, 1912, 37, 183), and Cranfield has practically confirmed this (ibid., 1915, 40,439); the results are in each case given in a table. The formula $P=(K-14) \times 0.26$ gives results agreeing excellently with the mean figures, and on applying this relation to the sixty-two individual results of Cranfield, I find that thirty-two are below the figures actually found and thirty above, the differences being-

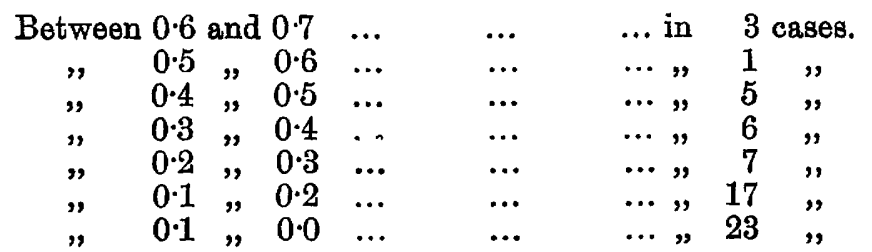

It may safely be assumed that if the Polenske figure is greater than $(K-10) \times 0.26$, the presence of coconut oil is established. 
The relation between the Reichert-Meissl (R) and Polenske (P) figures cannot be expressed by so simple a formula; from the results of over one hundred experiments I find that this formula gives a good agreement with butters and mixtures of butter and fats other than coconut oil.

$$
R \times 0.033-0.6155=\log .10(P-0.48) \text {. }
$$

In no case has the difference between the figures found and those calculated reached 0.7 c.c.

This formula may be used for calculating $\mathrm{P}^{\prime}$ in the formula for deducing the percentage of coconut oil that I have worked out ("Dairy Chemistry," second edition, p. 322) :

$$
\mathrm{C}=\frac{\mathrm{P}-\mathrm{P}^{\prime}}{14 \cdot 4} \times 100
$$

where $\mathrm{P}^{\prime}=$ mean Polenske figure calculated for a figure equal to the Reichert-Meissl figure and half the Polenske figure.

Both formulæ are approximations, and cannot be combined to express the relation between $R$ and $K$.

Boots Pure Drug Company, Lto.,

H. D. Richmond.

IsLaNd STREeT, NotTinghaM.

\section{ZEISS BUTYRO-REFRACTOMETER: THE CONVERSION OF SCALE READINGS TO REFRACTIVE INDICES.}

The formulæ given by C. C. Roberts (ANalyst, 1916, 41, 376) and J. F. Liverseege (ibid., 1919, 49) are both more cumbersome than are necessary, and simplify down to-

$$
287 \cdot 7-x=839 \cdot 4 \times \sqrt{1 \cdot 5395-[n] \mathrm{D}} .
$$

With four-figure logarithm tables both $x$ (scale reading) and $[n]_{\mathrm{D}}$ can rapialy be calculated from this formula. Roberts's and Liverseege's formulæ do not give quite identical results, and mine agrees with that of Roberts.

Boots Purt Drug Company, Ltw.,

H. D. Richmond.

Island STIEET, NOTTINGHaM.

\section{NOTES ON ALCOHOL.}

In a previous paper (ANALYst, 1897, 32, 154) I gave some formulæ for converting different statements of alcoholic strength. Since then Thorpe's tables have been published. Below I give the formula recalculated from his more correct data.

$$
\begin{aligned}
\text { Per cent. } & =\frac{0.79359 v / v}{\mathrm{~S}}=\frac{w / v}{\mathrm{~S}}=\frac{0.45257 \mathrm{P}}{\mathrm{S}} . \\
v / v & =\text { Per cent. } \times 1.2601 \mathrm{~S}=1.2601 w / v=0.5710 \mathrm{P} . \\
w / v & =\text { Per cent. } \times \mathrm{S} \quad=0.79359 v / v=0.45257 \mathrm{P} . \\
\mathrm{P} & =\text { Per cent. } \times 2.2096 \mathrm{~S}=1.753 v / v=2.2096 w / v . \\
\mathrm{S} & =\text { specific gravity at } 60^{\circ} / 60^{\circ} \mathrm{F} . \\
\text { Per cent. } & =\text { grms. of absolute alcohol per } 100 \text { grms. } \\
v / v & =\text { c.c. absolute alcohol per } 100 \text { c.c. } \\
w / v & =\text { grms. of absolute alcohol per } 100 \text { c.c. } \\
\mathrm{P} & =\text { c.c. proof spirit per } 100 \text { c.c. }
\end{aligned}
$$

44, BhoAd StReet,

J. F. LIVERseage. 